\title{
Funkcia intratextuálnych a intertextuálnych väzieb v poetologickom systéme debutu Ivany Dobrakovovej Prvá smrt' $\checkmark$ rodine
}

\section{Marcel Forgáč}

FORGÁČ, M.: The Function of Intra- and Intertextual References in the Poetological System of Ivana Dobrakovová's Debut Prvá smrt' v rodine (First death in the family) SLOVENSKÁ LITERATÚRA, vol. 68, 2021, no. 5, pp. 514-528

DOI: https://doi.org/10.31577/slovlit.2021.68.5.3

ORCID ID: 0000-0003-1078-2061

Key words: Ivana Dobrakovová, intratextuality, intertextuality, implied author, autobiography

The article analyses the function of intra- and intertextual references in Ivana Dobrakovová's first book Prvá smrt'v rodine (First death in the family, 2009), taking the principle of disintegration as the basic principle of Dobrakovová's writing. As a result of author's intratextual work, the texts transgress the genre of short story and foreground the monoperspectival narrative consciousness. This in turn leads to a pronounced relativisation of the position of the narrative category of character and to situationally constituted narrative forms as related to the "theme-problem" horizon of the work. Intertextual work, on the other hand, contaminates the monoperspectival narrative consciousness and in this way disqualifies it. The principle of disintegration leads to an accentuation of the presence of the implied author which in turn makes the text seem more autobiographical. The figure of the implied author (which can never be identified with the empirical writer) is aesthetically productive: although it is fully governed by the poetics of the text, it also allows the readers to evoke the empirical author. The poetics thus creates conditions for ambivalence - the analysed texts can be read both as fiction and as autobiography. 
V súvislosti s tvorbou Ivany Dobrakovovej literárna kritika zväčša konštatovala talentovanost' autorky (výberovo Součková 2012: 52; Taranenková 2010; Bžoch 2009) a originalitu jej autorského rukopisu (Prušková 2010: 20; Suchánková 2010:35). Zároveň je však táto talentovanost'a konštatovaná originálnost' komunikovaná (často dialekticky) prostredníctvom stopovania či projektovania rôzneho stupňa inšpirácie alebo súbežnosti autorkiných poviedok s dielami vel'kých mien literárnych dejín. Podla Lucie Sekáčovej v debute I. Dobrakovovej „badat' inšpiráciu existencialistami [...] siaha však až k priekopníkovi existenciálnych tém Franzovi Kafkovi“ (Sekáčová 2013: 72), a preto neprekvapuje, že ,autorkinu tvorbu literárna veda dáva do súvislosti práve s autormi, ktorých tvorba nesie značku kafkovskej poetiky (napr. D. Mitana, V. Balla)“(Sekáčová 2013: 72). Zora Prušková vo vztahu k Dobrakovovej tvorbe vníma ,zvláštny druh cortazárovskej textovej diskurzivity“ (Prušková 2010: 20). Filiácie s dielami Julia Cortázara, ale aj Dušana Mitanu, Pavla Rankova, Ballu či Jaroslava Rumpliho verbalizuje aj Vladimír Barborík (Barborík 2011: 115-117). Mária Klapáková potom označuje Dobrakovovú ako svetovú autorku, pretože jej texty „úplne napíňajú tendencie vo svetovej próze“ (Klapáková 2015: 48), ktoré sa vyznačujú ,skôr príklonom k (hyper)realistickému zobrazeniu, ktoré je deformované prizmou postavy (napr. jej výrazným cynizmom či dlhodobou konfrontáciou a neschopnostou vyrovnat'sa s negatívnou skúsenostou) “ (Klapáková 2015: 48). To možno dialogicky sprevádzat' poznámkou L. Sekáčovej, ktorá v nadväznosti na výskum Antona Popoviča upozorňuje na úskalie literárnych prvotín spočívajúce „v tvorbe takého literárneho modelu sveta, ktorý nie je budovaný na základe analýzy reality, ale len na báze textovej štylizácie“ (Sekáčová 2013: 79). Súvisí to s Popovičovým predpokladom, že debutujúci autorský subjekt ešte nie je, respektíve nemusí byt' vo vztaha k predchádzajúcemu literárnemu vývinu vykryštalizovaný, čoho dôsledkom sa môže stat' produkovanie množstva nefunkčných medzitextových relácií, kalkul či netvorivá adaptácia (Miko - Popovič 1978: 290-291). Z príbuzného stanoviska vedie svoju kritiku V. Barborík, ktorý v Dobrakovovej debute rozoznáva „riziká literarizácie“ (Barborík 2011:113); tie podl'a neho spočívajú v „x-tej variácii na dávny, kedysi azda produktívny a stále znova oživovaný literárny model“" (Barborík 2011:115), pričom „,ýsledkom pokusu o, spestrenie‘ neširokej, no velmi pevnej vnútornej základne ,zvonku' dodanými ozvláštneniami, teda výsledkom pokusu o ,literarizáciu‘ bolo oslabenie výpovede či priamo strata jej fundamentu“" (Barborík 2011: 116).

Intertextuálny pôdorys Dobrakovovej debutovej zbierky bol teda literárnou kritikou zretel'ne pomenovaný a odvodzovali sa z neho tak pochvalné, ako aj kritické hodnotiace súdy. V nasledujúcich úvahách mu chcem prisúdit' funkčnú charakteristiku, ktorá zdôrazní sémantický potenciál samotného uplatnenia intertextuálnych väzieb v prospech podporenia základného problémového okruhu knihy. V napätí k vyššie prezentovanému kontextu, vypovedajúcemu o nevykryštalizovanosti debutujúceho autora, chcem dokladovat', že ide o stratégiu, ktorá dotvára tematické (a genologické) aspekty vybraného diela z roviny naratívneho koncipovania textu. 

stane najzretel'nejšou v komparatívnom postavení, v ňom sa koniec koncov sémanticky prejavuje. V prvom kroku preto upriamim pozornost' na autorkino uplatnenie intratextuálneho princípu. Jeho presadenie v jej tvorbe je masívne a možno tvrdit', že je to jedna z recepčne najviditel'nejších textových stratégií, ktorej účinkom nie je len ustanovenie homogenity „literárneho sveta, ktorý trpezlivo a ciel'avedome kultivuje vlastný textový modus vivendi“ (Prušková 2010:20), ale aj posilňovanie autobiografického aspektu zobrazenia.

I

Estetika debutu I. Dobrakovovej je založená na viacnásobnej realizácii princípu rozpadu, ${ }^{2}$ to jest zrútenia, upadania, degenerácie, incidentu, trieštenia, straty, dekompozície, deformácie a nakoniec aj metamorfózy. Dobrakovová tento princíp uplatňuje na viacerých rovinách výstavbovej hierarchie - predovšetkým je ním organizovaná morfológia tematických aspektov, ktoré funkčne spolupracujú so stratégiou modelovania personálnej témy. Možno ho však identifikovat' a analyticky dokumentovat' aj z inej roviny - z roviny genologického rámcovania.

Princípu rozpadu (dekompozície) na najvyššej-genologickej - úrovni vyhovuje predovšetkým žánrová forma poviedky a následné produkovanie knihy ako zbierky poviedok, ktoré dokumentujú či predvádzajú incidentné momenty v topografii života postáv. Poviedka, ako ju Dobrakovová organizuje v knihe Prvá smrt'v rodine, sa stáva výsledkom rozpadu širokej architektoniky autorkinej centrálnej témy a problému na menšie, situačne ukotvené plochy ${ }^{3}$-je teda čiastkovým/ zlomkovým textovým výstupom, ktorého sprievodným účinkom je okrem iného komunikovat' znepokojujúcu neplnohodnotnost' (v zmysle fragmentu ako zostatku rozbitého celku), dotvárajúcu tematické, problémové i personálne orientácie Dobrakovovej písania z úrovne genologického tvarovania textu.

Dobrakovovej poviedka teda nefunguje v zbierke celkom autonómne či vyvážene (kvantitatívne i kvalitatívne), čomu v esteticky produktívnom napätí zodpovedá tendencia $\mathrm{k}$ (sebazáchovnému) scel'ovaniu. Tá je založená na „vzájomnej pomoci“ textového okolia, teda na pedantnom vypracovaní zložitej intratextuálnej siete vnútorných korešpondencií, vzt'ahov a kryštalizácií, ktorá spája

1 Už Lubomír Doležel upozornil na neúmernú rozl'ahlost' Kristevovej chápania intertextuality (Doležel 2003: 197-199). V príspevku pracujem s jej užším vymedzením; v nadväznosti na výskum Manfreda Pfistera a Ulricha Broicha chápem intertextualitu ako „vedomé, intendované a vyznačené vztahy medzi textom a existujúcimi textami alebo skupinami textov" (Jambor 2016: 230).

2 Ivana Taranenková konštatuje, že I. Dobrakovová v procese produkcie románu Bellevue „,iahla k najvýraznejším motívom minuloročného úspešného debutu, zbierky poviedok Prvásmrt'v rodine a zjednotila ich v prozaicky rozsiahlejšom celku“ (Taranenková 2010). Knihu zároveň číta ako „román o psychickom rozklade“, pričom uvádza aj tieto charakteristiky: „Blanka je neustále orientovaná ,chrbtom k svetu“, všetky svoje vzt'ahy podrobuje dôkladnej analýze a následne ich deštruuje, nedokáže to zmenit', aj ked' sa o to pokúša. Takto ničí svoj vztáah k priatel'ovi Petrovi, ale aj k lud'om, ktorých spoznala v tábore. [...] Jej príbeh sa končí kapituláciou, v dovŕšenom psychickom rozklade“ (Taranenková 2010). Princíp rozpadu považujem za jeden z prenosných aspektov Dobrakovovej tvorby, jeho rozpracovanie v románe Bellevue je geneticky späté s výrazom poviedkového debutu, najmä s poviedkou Bellevue, Marseille.

3 V. Barborík v tejto súvislosti kriticky hovorí „o rozdrobení jedného rozprávania na epizodické sekvencie krátkych príbehov, kde nutnost' odlišit nasledujúci text od predchádzajúceho rozmieňajú pôvodnú jednotu rozprávajúceho subjektu na drobné mince pokusov permanentne inovovat zápletky a pointy“ (Barborík 2011: 116). 
jednotlivé čiastkové (zlomkové) plochy do „príbuzenstva“, do „rodín“. Tie fungujú na princípe dedičstva, teda na delegovaní a híbkovom kultivovaní semiotických príznakov, tematických aspektov, štýlovo-naratívnych modalít, personálnych typov, ale aj situačných reakcií postáv, ich skúsenostných evidencií, charakterových vlastností a podobne. $\mathrm{V}$ tomto zmysle možno $\mathrm{v}$ analyzovanej zbierke rozoznat' výraznejšie morfologicko-tematické vrstvenie. V rovine témy sú na probléme dedičstva/dedičnosti založené poviedky, ktoré v intratextuálnych reláciách kooperujú na vytvorení zázemia knihy (On a ona. Nie my dvaja; Dedičstvo; Matka a dcéra cestujú vlakom; Apuka; Žit's Petrom). Vo vztahu k tomuto okruhu poviedok sa v literárnokritickom priestore ustálila interpretačná línia centralizujúca predovšetkým motívy otca a manicko-depresívnej psychózy. ${ }^{4}$ Spresňujúcim korektívom by mohlo byt' tvrdenie, že I. Dobrakovová v tomto poviedkovom súbore kladie omnoho väčší dôraz na problém (potenciálneho) prenosu psychických (in)dispozícií rodinne príbuzných postáv; autorské gesto sa tu teda orientuje na tematizáciu (potenciálnych) dôsledkov vyplývajúcich zo vztahu postáv, nie na predvedenie psychologického modelu jednej postavy. V Dobrakovovej tvorbe sa presadzujú motívy tela, telesnosti a sexuality, v okruhu debutových poviedkových výrazov je však rovnako dôležitým modelujúcim prvkom princíp videnia, pohladu, očí, teda vizuálnej evidencie, ktorá v kombinácii s psychotickým stavom má potenciál stvorit' osobný model/rozmer skutočnosti. V autorkinom estetickom systéme založenom na princípe rozpadu je toto jediná tvorivá moc, ktorá (tematickú) skutočnost'nespochybňuje, ale ju nanovo kladie, a to vo vyhranene subjektívnom, psychologicky intímnom, a preto o to viac osobne autentickom výraze. Tieto poznámky možno dokladovat' interpretačnou rekonštrukciou. Poviedka Matka a dcéra cestujú vlakom iniciuje situáciu (Blanka s matkou cestujú vlakom za otcom), ktorá má až do pointy charakter zobrazenia prirodzeného života postáv. Pointa odhalí, že ide o detskú rolovú hru, ktorú však prerušuje iba matka. V uplatnenom deformačnom princípe, rozkrývajúcom navodenú skutočnost' ako hru, nakoniec dochádza k vyhodnoteniu podporovania detskej predstavivosti ako potenciálne ohrozujúceho konania: „Dávam jej nádej, že sa s tatinom raz stretne. Nakoniec si ho vsugeruje. Vymyslí. Zbledla som. Čo aktieto banálne cesty vlakom u nej vyvolajú nejakú psychickú poruchu? Začne počut' hlasy a bude si mysliet', že k nej hovorí tatino “ (Dobrakovová 2009: 21). Motív detskej hry je uplatnený aj v poviedke Apuka: otec, ktorý sa s dcérou ubytuje v šope, pretože v prednom dome „už niekto býva“ (Dobrakovová 2009: 24), sa z pohl'adu dcéry „asi len tak hrá, hrá sa na vojnu s neviditel'nými nepriatelmi, ako sme sa aj my s bratrancom hrávali s umelohmotnými Indiánmi“ (Dobrakovová 2009:28-29). V poviedke Apuka je neustále zviditelňované rozhranie perspektív, pomerne zretelne sa diferencuje dcérin konvenčný, ustálený spôsob vnímania od otcovho halucinačno-paranoidného: „Vyzerala som spoza kríka, žmúrila do slnka, zacláñala si oči, robila som všetko, čo bolo v mojich silách, aby som ich uvidela, išla som si oči vyočit', ale napriek tomu by som mohla odprisahat, že vprednom dome nikto nie je“ (Dobrakovová 2009: 28). Napriek zdôraznenému diferentnému zobrazeniu však dochádza k dvom zásadným krokom: dcéra situačne prijíma otcovu perspektívu, otcovu „hru“, nevytvára teda

4 Napríklad Michal Jareš zdôrazňuje modelovanie figúry otca a motívu otcovstva v prvých poviedkach, čo sa mení v zbierke Toxo, v ktorej je dôraz kladený na postavy matiek (Jareš 2013: 13-18). 
priepast', ale začína byt' na tejto perspektíve účastná: „Podvedome som ajja dávala pozor na zvuky a zdalo sa mi-aj ked'som si to možno len nahovárala-, že v prednom dome naozaj niekto je, počula som hlasy, ale nedokázala som zachytit'slová, a tiež zvuky, možno posúvanie stoličiek, otváranie okna, kroky, nevedela by som to presne určit', ale bola som si istá, že sa tam niečo naozaj hýbe" (Dobrakovová 2009: 25). Neskôr si však zaumieni, že predný dom preskúma „na vlastné oči, ako to s ním je, či tam niekto býva, alebo sa otec trasie pred prízrakmi“" (Dobrakovová 2009: 31). Vôla $\mathrm{k}$ racionalizácii a verifikácii je tu mimoriadne silná, dcéru vracia na východiskovú pozíciu a spôsobí otvorenú konfrontáciu s otcovou perspektívou: „apuka, to som ja, som v zadnej miestnosti, nikto tu nie je, nemusišs sa bát'! [...] apuka, môžě̌ tú sekeru odložit', nikto tu nie je. Otec akoby zaváhal, ale sekeru neodložil" (Dobrakovová 2009: 32). ${ }^{5}$ Naznačený oblúk dotvára poviedka On a ona. Nie my dvaja. Inscenuje náladovú labilitu mladej ženy z pohl'adu jej staršieho milenca (prezývaného otec). Sémantickým jadrom krátkeho textu sa stáva pomenovanie príčin ženinej nevyrovnanosti, ktoré môžu byt' (pre)dispozične viazané na manicko-depresívnu psychózu jej zosnulého otca. Naplno je tu aktivovaná otázka o potenciálnej dedičnosti choroby, ktorá bola $v$ iných textoch iba naznačovaná (prostredníctvom matkiných obáv a dcérinho prijímania otcovej perspektívy): „vedela si napríklad, že predispozícia na manicko-depresívnu psychózu je desat' percent, ak ňou trpel jeden $z$ rodičov, a ak boli chorí obaja rodičia, až pät'desiat percent [...] celkom slušná pravdepodobnost', nemysliśs? “ (Dobrakovová 2009:9). Poviedka Dedičstvo završuje túto líniu d'alšou fázou. Situačne ukotvené rozprávanie tu už produkuje halucinačné vidiny (intratextuálna väzba na poviedku Matka a dcéra cestujú vlakom je zrejmá), ktoré sú rámcované výpoved'ou: „Otec s nami ostáva celý život. Možno aj dlhšie. Alebo aspoň môj otec" (Dobrakovová 2009: 13). Je evidentné, že titulným dedičstvom tu nebude zdedený dom, ale psychotické prejavy dcéry, ktorá vidí mŕtveho otca. Vymedzený poviedkový materiál teda zaznamenáva vývinový proces: detská predstavivost' (hra) zosilnená v postave otca $(A p u k a)$ je jednotlivými poviedkami postupne usmernená do podoby zdedenej choroby.

Vyššie reflektovaný problém je v rámci Dobrakovovej tvorby natol'ko dominantným tematickým okruhom, že bude tieňovat', respektíve bude potenciálne prítomný alebo čitatel'sky projektovaný do charakteristík takmer všetkých ostatných postáv. Dobrakovovej postavy (aj z jej iných diel) budú mat' odteraz

5 Tento postup je aktualizovaný v poviedke Žit's Petrom, ktorá uvádza postavu mladej ženy Ireny. Tá sa konfrontuje s vidinami svojho manžela Michala - v spoločnej domácnosti začínajú žit's Michalovým priatel'om Petrom. Irenina rozprávačská pozícia neustále zdôrazňuje rozhranie perspektív, pomerne zretel'ne tak diferencuje konvenčný, ustálený spôsob vnímania na strane vypovedajúcej manželky a Michalov halucinačný spôsob vnímania (v ktorom sa aj ona sama môže stat' halucinačným prízrakom). Napriek zdôraznenému diferentnému zobrazeniu dochádza aj tu k dvom zásadným krokom. Naratívne vyčlenenú Michalovu perspektívu Irena najprv prijme: „Tak som to teda prijala so sklonenou hlavou [...] Peter bude odteraz členom našej rodiny a ja sa mu pokúsim vytvorit' prijemné prostredie, aby sa u nás dobre cítil [...] po čase som bola nútená pripustit', že Peter existuje, že ked' sa takto správam, že ked'sa mu takto prispôsobujem, jednoducho musí existovat', rovnako ako ja a Michal. A začala som si ho predstavovat', toho Petra, nejako predsa musí vyzerat' a v mojich očiach bol vysoký, tmavovlasý, a navyše aj so zlomeným nosom, neviem prečo, ale ten zlomený nos som videla celkom zretel'ne“ (Dobrakovová 2009: 119-120). Neskôr ju však razantne odmietne: „tvoj Peter vôbec neexistuje, nikdy neexistoval a ani nebude, počuješ ma? [...] Peter je len tvoja utkvelá predstava, len chiméra! halucinácia! blud! nazvi si to, ako chceš, nič sa na tom nezmení [...] videla som, že Michal sa čoraz viac stahuje do seba [...] že by mi aj chcel uverit', ale predsa, na vlastné oči, ako by mohol popriet' niečo, čo na vlastné oči“ (Dobrakovová 2009: 122). 
svoj fundament (bez ohl'adu na to, či bude alebo nebude textovo exponovaný), s ktorým budú explicitne či implicitne komparované, jeho prostredníctvom budú vo väčšine prípadov nahliadané a tým aj konceptualizované: „Na túto výraznú prozaičku mladšej generácie sa nalepili isté interpretačné schémy, ktoré z nej vytvorili autorku píšucu najmä o psychických chorobách a emocionálnej labilite“ (Bystrzak 2018). Marcelina podivná rezervovanost' (Klbko hadov), Natašin vaginizmus vyplývajúci z traumy z detstva (Ti bos zelo v redu puca) alebo Lízino zrútenie do polohy rezidenta ústavu Bellevue (Bellevue, Marseille) - napriek rozličným miestam, situáciám i menám postáv - nič z toho už nedokáže v rámci zbierky založit' takpovediac nový okruh témy a problému. Dôvodom je autorská preferencia jednotného naratívneho vedomia, „ktoré sprostredkúva svet [...], pričom je jedno, v akej rozprávačskej forme sa prejavuje“ (Barborík 2011: 115).

Účinok uplatnenia intratextuálneho postupu je teda viacvrstvový. Nielenže na pozadí organizovanej neplnohodnotnosti zviditelňuje a zdôrazňuje vzájomnú odkázanost' (poviedok), ale tiež upevňuje koncepčný princíp rozpadu sugerovaním d'alšej výraznej straty - silná intratextuálna previazanost' poviedok totiž spôsobí, že „sa stráca poviedkový charakter knihy“ (Ferenčuhová 2009), „žánrové určenie je tu skôr formálne“ (Suchánková 2010: 34). Strata tvaru reality, hraníc normality či logického usporiadania, ktorá sa v debute viacnásobne prejavuje napríklad aj iniciovaním manicko-depresívnych stavov, groteskného vykíbenia situácií v podobe bizarných point, hyperbolou, expresívnostou či neurotickostou výrazu - všetko je to funkčne rámcované (predikované, sprevádzané a podporované) stratou genologickej identity samotného textu. V tomto zrútení o to viac vystupuje do popredia ono ,zranené“ (Barborík 2011: 114), avšak jednotné a scelujúce monoperspektívne naratívne vedomie, ${ }^{6}$ ktoré sa vyznačuje (v slovenskej literatúre) nezamenitel'ným privátnym výrazom. Literárna kritika v tejto súvislosti uvažuje o biografickosti (Prušková 2010: 19-24; Barborík 2011: 113-118), o „presadzovaní uvedomeného autobiografického písania, založeného na existenciálnej imaginácii ,rozličných situácií a výziev individuálneho života (Gumbrecht)“ (Zajac 2013: 17), o „monoperspektívnom rozprávaní s osobným ručením" (Barborík 2011: 115).

Dominantné postavenie monoperspektívneho naratívneho vedomia sa v Dobrakovovej debute Prvá smrt'v rodine prejaví predovšetkým umenšovaním či relativizovaním významu jednotlivých postáv vo vztahu k tematickému horizontu zbierky. V tejto súvislosti je nutné odmietnut' predstavu, že Dobrakovová pracuje s množstvom samostatných postáv, a teda aj samostatných príbehov, ktoré sú s nimi jednotlivo spojené. V skutočnosti je jej zbierka „zaludnená“ viac menami než postavami, ked'že tu dochádza len k premenovávaniu jednej naratívno-personálnej perspektívy. Tá tvaruje „svet a udalosti“ zbierky a garantuje ich homogénnost' - je to „svet“ jednotný, svet zúžených priestorových či sociálnych

6 „Figúru“ monoperspektívneho naratívneho vedomia, ktoré sa odlišuje od situačne komponovaných rozprávačov uplatnených v jednotlivých poviedkach, abstrahujem z interpretačnej poznámky V. Barboríka: „Personálny aspekt zaručuje zbierke jednotu a presvedčivost': sú to rozprávania s osobným ručením. Ale aj rozprávania monoperspektívne, ked' väčšinou poviedok prechádza stále ten istý rozprávajúci subjekt. Rizikom - vzhl'adom na celok knihy-je monotónnost', opakovatel'nost'. Nie je to len problém jazyka, motívov a prostredia - predovšetkým sa opakuje aj podoba vedomia, ktoré nám sprostredkúva svet [...], pričom je jedno, v akej rozprávačskej forme sa prejavuje“ (Barborík 2011: 115). 
520 kulís, ${ }^{7}$ plný naliehavých, neurotických viet, ktoré produkujú deformačný účinok vo vztahu k väčšine dotknutých tematických momentov (otec, rodina, telo, sexualita, priatel'stvo, vztah, medziludská komunikácia a podobne).

$\mathrm{V}$ súvislosti s pôsobením monoperspektívneho naratívneho vedomia však možno evidovat aj jednu problémovú intenciu, ktorá ho v konečnom dôsledku diskredituje. Dochádza k tomu v momente, ked' Dobrakovovej naratív začína svoju tému-doteraz valorizovanú ,osobným ručením“(V. Barborík)-koncipovat v cudzích, literárne kanonizovaných sekvenciách (mám na mysli predovšetkým „kafkovské poviedky“ Tik, Navyše, Balkón, ... ale tie dlhé múry sa tak rýchlo zbiehajú). Výrazovým registrom i tematickým zameraním bola doteraz posilňovaná predovšetkým tonalita privátnosti monoperspektívneho naratívneho vedomia, jeho koncipovanie témy (sveta, udalosti, problému) bolo takpovediac vlastnoručné, tu sa však začína zviditelňovat jeho odvodenost. Za týchto intertextuálnych okolností zbierka síce dotvára sémantické horizonty textov ideovo závažnými alúziami, ${ }^{8}$ avšak recepčne evidujeme - ako na to upozornil už V. Barborík - ,oslabenie výpovede či priamo stratu jej fundamentu" (Barborík 2011: 116). Intertextualita ako postup sprevádzajúci tvarovanie privátnych tém v Dobrakovovej debute, no takisto v jej dalš̌ej tvorbe, vstupuje do výrazného napätia s navodzovanou osobitostou monoperspektívneho naratívneho vedomia. Intertextualita je tu teda skôr rozrušujúcim než konštituujúcim postupom. To platí pre celok Dobrakovovej tvorby, predsa len, nejde o autorku generálnych reflexií či typizovatel'ných postáv, ale individuálnych, no najmä neprenosných evidencií. Ak Kafkova postava „,nese svůj úděl jako kabát šitý na někoho obrovitého [...] Jako by se do toho kabátu měli vejít všichni ostatni“' a tým „,yjadřuje životní situace všeobecné platnosti a mluví i za jiné, za nás, za všechny“, a teda „vkládá do hry i náš život“ (Černý 1969: 133-134), Dobrakovovej naratívne vedomie hovorí jedine za seba a „do hry vkladá“ jedine svoj život. Pokial' Kafkove prózy vytvárajú príbehy ako „,vzory děni““a sú orientované mytologicky (Černý 1969:134), Dobrakovovej prózy sú orientované symptomaticky, jej najsilnejšie „príbehy“ sú neprenosné, neodkazujú k žiadnemu zákonu či nadosobnému princípu, sú vpadnuté samy do seba a obrátené jedine k sebe samým. Sú sebavýpoved'ou. V tom spočíva ich základná, čitatel'sky akceptovatel'ná, esteticky produktívna pozícia. Každý pokus o prepólovanie týchto charakteristík, každý pokus o ich podmienenie a vyjadrenie cudzím výrazom cudzieho textu vyznieva v Dobrakovovej tvorbe neprimerane, štylizovane, rušivo, ako odstúpenie od týchto základných pozícií, ako strata fundamentu výpovede (V. Barborík).

\section{II}

Oslabenie monoperspektívneho naratívneho vedomia, ktoré je dôsledkom uplatnenia intertextuálnych väzieb, sa však nemusí nutne spájat aj s oslabením estetického

7 Súčastou estetiky I. Dobrakovovej sú výrazne zúžené priestorové i sociálne kulisy; niekol'ko výraznejšie nešpecifikovaných postáv sa stažka a problematicky orientuje predovšetkým v izbách, v domácnostiach, na uliciach cudzích miest, na balkónoch, v posteliach či od okolia separovaných kempoch, ktoré svojím vnútorným usporiadaním produkujú množstvo d'alších hraníc, deformujúcich možnost' rozvinutia potenciálnej sociálnej priechodnosti. Táto poznámka je vol'ne orientovaná Klapákovej interpretáciou sémantických (symbolických) línií topografických určení v Dobrakovovej tvorbe (s dôrazom na román Bellevue) (Klapáková 2012: 927-934).

8 Dôsledne ich interpretovala Lucia Sekáčová (Sekáčová 2013: 72-80). 
účinku Dobrakovovej debutu a netreba ho vysvetl'ovat' ako prejav nevykryštalizovanosti debutujúceho autora, ktorý sa opiera o tradíciu a cudzie modely zobrazenia. Uplatnenie intertextuality tu totiž možno vyhodnotit aj ako významotvorný proces.

Dobrakovovej použitie intertextuálneho princípu spochybňuje schopnost' naratívneho vedomia udržat' monoperspektívny privátny výraz. Ono naratívne vedomie, sústredene prezentované vo väčšine textových blokov, začína približne od polovice knihy ${ }^{9}$ signalizovat' svoju odvodenost', čím dochádza k strate pôvodne asociovanej hodnoty „osobného ručenia“. Toto spochybnenie je zviditel'nené tým, že intertextovost' sa presadzuje ako pamät textu' ${ }^{10}$ (a teda predstavuje kontraindikáciu voči rozvíjanej existenciálnej celistvosti figúry monoperspektívneho naratívneho vedomia). Dobrakovovej situačné opretie sa o intertextualitu je tak prejavom dôsledného uplatnenia princípu rozpadu - tentoraz zameraného na samotné naratívne vedomie. Intertextualita kontaminuje naratívne vedomie nepôvodnostou, čím ho vnútorne rozkladá. $\mathrm{V}$ tomto zmysle je použitie intertextuálnych postupov sofistikovaným znakom, reprezentujúcim zrútenie „vlastného hlasu“ naratívneho vedomia zbierky. V centre naratívnej roviny je vytvorený rozkol: významové jadro zbierky, ktoré sa podiel'a na tonalite privátnosti zbierky, ostáva platné, no naratívne vedomie je situačne diskreditované - už nemôže byt' garantom „osobného ručenia“.

Jedinou figúrou, ktorá z tohto zrútenia môže vytažit' a podopretím výrazového jadra zbierky posilnit' svoju pozíciu, je nakoniec figúra, ktorá by podla všetkých kondolencií mala byt' „mŕtva“ (Roland Barthes) - figúra autora.

\section{Protipohyb}

Masívnym uplatnením intratextuálneho postupu dochádza k strate genologickej identity diela - zbierka poviedok sa javí ako jedno (stavebne fragmentarizované) rozprávanie, jedna výpoved'. V takto realizovanej intratextuálnej modalite dochádza k spochybneniu autonómie jednotlivých postáv - postavy nesú rôzne mená, no zároveň sú vo vztahu k tematizovaným udalostiam zamenitel'né, sú teda neplnohodnotnými textovými figúrami bez vlastného jazyka, a teda bez ,vlastného výrazu“. ${ }^{11}$ V tejto súvislosti vystupuje do popredia „monoperspektívne naratívne

9 Všetky výrazne intertextuálne komponované poviedky sú umiestnené do pomyselnej druhej polovice zbierky (Balkón, Liečebné kúry, ... ale tie dlhé múry sa tak rýchlo zbiehajú, Tik).

10 Vychádzam z koncepcie Renate Lachmannovej, na ktorú odkazuje Shamma Schahadat (Schahadat 1999: 362).

11 Kategória postavy tu podlieha účinku uplatnenia intratextuálnej stratégie, ktorá ju vo vztahu k téme konštituuje ako neautonómnu, situačnú a zamenitel'nú figúru. Heterogénnej onomastike tu teda sekunduje homogenizačný princíp, ktorý je založený na úzkom registri jazykovo-výrazových (štylistických) prostriedkov monoperspektívneho naratívneho vedomia. Postavy majú rozličné mená, no jednotnú modalitu existencie, ktorá je produkovaná nadradeným monoperspektívnym naratívnym vedomím. V nadväznosti na štúdiu W. Walsha Kdo je vypravěč? možno konštatovat, že to nie je tak, že postavy a naratívne formy jednotlivých poviedok sú zdrojom jazyka (vypovedania, tvarovania témy), ale jazyk monoperspektívneho naratívneho vedomia je zdrojom postáv a situačných naratívnych foriem - tie sú teda výsledkom uplatnenia jedného jazykovo-výrazového registra. V tejto situácii sa rôzne postavy nedokážu uplatnit' inak než ako zástupné, len situačne ukotvené prostriedky, ktoré možno bez konzekvencií opustit'/vymenit'. Reprezentatívnym príkladom tejto skutočnosti sa stávajú postavy síce s rôznymi menami, ale prežívajúce v rozličných textoch tie isté udalosti. Najvyhranenejšie to ukazuje vztah poviedky Marseille, Bellevue a románu Bellevue, v ktorom postava Blanky preživa to, čo pred ňou poviedková postava Lízy. 
522 vedomie“, jeho výsadná pozícia je však rozrušená uplatnením intertextuality, normy a hodnoty implikované textom mu nemožno vždy pripísat' (Müller 2012: 208).

Uplatnením intratextuálneho a intertextuálneho princípu nechala I.

Dobrakovová rozpadnút sa všetko, čo v literárnom systéme stojí medzi figúrou autora, a tým, čo je rozprávané (najmä pozície, ktoré v literárnom texte „prekrývajú “ figúru autora tým, že nesú príznak „personalít“ - narátora a postavy). Je to stratégia „škrtania“, ktorou sa dosahuje velmi špecifický účinok: na strane čitatel'a sa iniciuje, organizuje a zosilňuje povedomie o prítomnosti autora v tom, čo je rozprávané. V konečnej fáze sa zdá (má sa zdat'), že v tomto poetologickom systéme zostáva prítomná a platná iba „Dobrakovová“ a „to, čo je rozprávané“ („rozprávané Dobrakovovou“).

Táto formulácia zachytáva „pokušenie“, ktoré svojimi stratégiami distribuuje analyzované dielo smerom k čitatel'ovi, no je nutné vykonat' jej korektúru: Dobrakovovej realizácia „škrtania“v skutočnosti neiniciuje a nezdôrazňuje prítomnost' figúry autora, ale figúry implikovaného autora. ${ }^{12} \mathrm{Ib}$ prostredníctvom tejto figúry vystavuje čitatela (celkom účelne) pokušeniu podmienit'a usúvzt'ažnit' udalosti textu s empirickým autorom. ${ }^{13}$ Zdôraznenie prítomnosti implikovaného autora v texte je preto možné vysvetlit ako prostriedok, ktorým Dobrakovová projektuje autobiografický (de jure faktuálny) aspekt svojich fikcií. ${ }^{14}$

Uvažovat' o autobiografickom aspekte Dobrakovovej fikcií a jeho účinku je pomerne vel'kým rizikom, jej poviedky k takémuto čítaniu viditel'ne nevyzývajú, dokonca sa možno domnievat', že tomuto čítaniu vlastne zabraňujú. Ich naratívy sú takpovediac obrátené chrbtom $\mathrm{k}$ sféram autora a v procese fikcionalizácie (termín Käte Hamburgerovej) ${ }^{15}$ neustále tvoria zámenné figúry. ${ }^{16}$ Textové udalosti sú teda komponované v podmienkach performatívu, ktorého „kód je vytvorený špecifickým rozvrhnutím znakov, figúr a schematických aspektov, ktoré reprezentatívne vytvárajú antropomorfné objekty“ (Kendra 2020:19). Autorské „Ja“ sa v Dobrakovovej tvorbe nestáva (vehementne manifestovaným/

12 Vychádzam z Chatmanovho znázornenia naratívnej komunikačnej situácie, ktorá má podobu: „reálny autor $\rightarrow$ / implikovaný autor $\rightarrow$ (vypravěč) $\rightarrow$ (adresát) $\rightarrow$ implikovaný čtenář $/ \rightarrow$ reálny čtenár “ (Chatman 2008: 157). Lomky (/) v tejto schéme vyznačujú priestor naratívneho textu.

13 Toto pokúšanie je pomenované Umbertom Ecom, ktorý na podklade Boothovho konceptu implikovaného autora vypracoval koncept modelového autora. V uvažovanom kontexte je cenná Ecova poznámka: „Modelový Autor však není pokaždé rozpoznatelný tak zřetelně a empirický čtenář se často ocitne v pokušení přizpůsobit se právě autorovi empirickému coby subjektu výpovědi, a to na základě informací o něm... Tato rizika a posuny činí občas z textové kooperace opravdové dobrodružstvi“" (Eco 2010: 80).

14 Podkladom pre úvahy o stratégii zosilňovania autobiografického aspektu v priestore autobiografickej fikcie bola úvaha G. Genetta o výpožičkách a výmenách medzi faktuálnym a fikčným naratívom, ktorá vrcholív poznámke: „narativní formy bez zábran překračují hranici mezi fikcí a ne-fikci“ (Genette 2007: 68). 15 Kontext termínu „fikcionalizácia“v koncepcii K. Hamburgerovej systematicky analyzuje a komentuje Dorrit Cohnová (Cohnová 2009: 29).

16 Ak D. Cohnová rámcovo vymedzuje autobiografickú fikciu ako „dílo vycházející z autobiografických zkušenosti' (Cohnová 2009: 47), vo vztahu k Dobrakovovej postupu to možno dopovedat' v tom zmysle, že Dobrakovová uprednostňuje fikcionalizáciu autobiografických skúseností pred autobiografizáciou fikčných konštruktov. 

snahu uniknút' z pol'a priamej mimetickej referencie.

Vyššie uvedené naznačuje rizikovost' rozvijania úvah o autobiografickom pôdoryse fikcií v tvorbe I. Dobrakovovej. To, čo ma k tomuto uvažovaniu vedie aj napriek rizikovosti, je skutočnost', že celá táto situácia je riadená zvnútra princípom rozpadu. Dobrakovová namiesto posilňovania kategórie postáv a rozprávačských foriem jednotlivých poviedok tieto figúry naopak spochybňuje, rozkladá, zviditelňuje ich nepôvodnost' vo vztahu k téme a problému, ukazuje, že sú „iba“ fantómovými agensmi deja a udalostí. Text tak nesie signál protipohybu - a práve z neho možno (nazdávam sa) vytažit' autobiografický aspekt fikcií: Dobrakovová ho neformuluje priamo referenciou k autorskému subjektu, ale nepriamo umenšovaním či spochybňovaním významu „textových personalít“ vo vztahu $\mathrm{k}$ tematicko-problémovému horizontu diela ako celku, ktoré ústi do zdôraznenia prítomnosti implikovaného autora.

Nárok na auto/biografickú reprezentáciu (či referenciu) najčastejšie naráža na postštrukturalistickú či postanalytickú antireprezentacionalistickú tradíciu (Richard Rorty), ktorá dokladuje, že ,jazyk jako takový - tedy nikoli jen umělecké texty - nereprezentuje, tj. pasivně neodráží autonomně dané entity světa, ale v podstatném smyslu je konstituuje“ (Skalický 2012: 65). Možno tiež uviest' neopragmatické stanovisko Vladimíra Papouška, ktorý v štúdii Maxwellův démon deklaruje: „Každý, kdo vypráví o skutečnosti, vypráví fikci“ (Papoušek 2017: 63). Je zrejmé, že sa to priam bytostne týka najmä autorských autobiografických zámerov. Autor usilujúci sa o textové sebazaznamenanie naráža na konštitutívne sily semiotiky textu: „Já, které vypráví o já, je samo vyprávěno vyprávěním, autor je produktem svého textu. Je dílem svého díla“ (Šmídová-Matoušová 2014: 242). Almut Finck celý tento odpor textu voči autobiograficky referenčným zámerom autora sumarizuje syntetizujúcou skratkou:

„Představa duality jazykového znaku, který sestává z jazykového označení a referentu, jenž není jazykové povahy, protože znaku předchází, je nahrazena pojetím jazyka jako řetězce signifikantů, které ve složitém vztahu vzájemného

17 Nie je to tak ani v poviedkach, ktoré sú realizované v móde homodiegetického (prípadne autodiegetického) rozprávania. Ak Dobrakovová v poviedkach aktivuje autodiegetické rozprávanie, odstup od figúry autora okamžite indikuje tým, že rôznym subjektom, situačne rozprávajúcim v prvej gramatickej osobe, priradí rozličné mená a rody. Zabraňuje tak tomu, aby mohla byt' perspektíva prvej gramatickej osoby zjednotená pod jedným menom a následne čítaná v autobiografickom móde. V tejto súvislosti si pozorný čitatel' iste všimne minimálne jednu poviedku, ktorá je realizovaná v homodiegetickom (autodiegetickom) móde rozprávania a v ktorej je rozprávačom a zároveň postavou Ivana. Ak by Dobrakovovej debut fungoval ako zbierka poviedok, bolo by možné rozlišit poviedky, v ktorých figuruje rozprávač-postava Ivana a reflektovat toto meno po vzore D. Cohnovej ako indíciu autobiografickej referencie (Cohnová 2009: 48). Dobrakovovej debut však charakter zbierky stráca a vyznačuje sa monoperspektívnym rozprávaním, ktoré je nadradené situačným zámenným naratívnym formám. V poviedke Dedičstvo je rozprávačom a zároveň hlavnou postavou Ivanka, avšak v poviedke Žit's Petrom je to Irena, v poviedke Po pohrebe je to Amália a v poviedke Noci je Sárou oslovovaná ako Sisinka. Zmena mien nedovoluje klasifikovat prvú osobu rozprávača v systémovo monoperspektívnom rozprávaní ako autobiografickú referenciu postavenú okolo mena Ivana. Meno „Ivana“ nemôže byt' priorizované, pretože má rovnaké postavenie ako mená „Irena“ alebo „Amália“- je len situačnou figúrou, ktorá bude nahradená inou situačnou figúrou rozprávajúcou v prvej osobe. Tým je meno „Ivana“ vo vztahu k oblasti autora de facto desémantizované. Ani samotná prvá osoba rozprávača sa v rámci celku diela neudrží a je „striedaná“ rôznymi inými naratívnymi formami (tretia osoba singuláru, druhá osoba singuláru). 

odkazování referenci-jakožto signifikát - teprve vytvářejí. Tento signifikát jakožto účinek pohybu označujících by pak nikdy nemohl být vně jazyka lokalizovatelným referentem, nýbrž vždy jen dalším označujícím. Proces signifikace jako proces, v nemž se význam - nikoli s konečnou platností - teprve konstituuje, by tedy nebyl výkonem subjektivního označování, nýbrž byl by to děj, v němž vzniká nejen každý význam, nýbrž stejně tak i subjekt sám. [...] Autobiograf, který se pokouši nabýt prostřednictvím jazyka jistoty o své subjektivitě, by pak tuto subjektivitu teprve produkoval, a produkoval by ji ve stejném mediu. Tradičně postulovaná identita mezi poznávajícím subjektem a objektem poznávání by se stala nemožnou právě tehdy, kdy by se jí subjekt snažil dosáhnout" (Finck 1999: 283-284).

Je zrejmé, že jazyk/semióza spôsobuje nemálo problémov, a to najmä s ohl'adom na rozvinutie autobiografického aspektu. Slovo totiž „,dává to, co značí, avšak nejprve to potlačuje [...] Když mluvím, popírám existenci toho, co říkám, ale popírám také existenci toho, kdo to ríká: pokud moje promluva odhaluje jsoucno v jeho neexistenci, tvrdí také, že toto odhalování probíhá na základě neexistence toho, kdo je uskutečňuje, na základě jeho schopnosti odstoupit od sebe sama, být jiný než svoje bytí. [...] V promluvě umírá to, co promluvě dává život“" (Blanchot 2004: 213-216). Ako k tomu poznamenáva Josef Fulka, Maurice Blanchot tu hovorí o tom, že ,jakákoli reference užitá ve fikci znamená okamžitě eliminaci, znepřítomnění objektu či jevu aktuálního světa, $\mathrm{k}$ němuž se fikčním pojmenováním odkazuje“ (Fulka 2004: 194-195). ,Ja“, majúce v úmysle autobiograficky vypovedat' (o) ,Ja“, v skutočnosti poskytne svoje bytie slovu byt $t^{\prime 18}$ a teda akurát si tak „zpívá vlastní pohřební pochod“ (Blanchot 2004: 214).

$Z$ uvedeného pre mňa vo vztáahu k Dobrakovovej debutu vyplýva jeden mimoriadny dôsledok: pre to, aby sa predtextové ,Ja/bytie“ "mohlo auto/biograficky udržat a presadit', by mohlo byt nápomocné, aby sa (paradoxne) pokúsilo v texte zaujat' semioticky neutrálnu pozíciu, aby sa takpovediac vyhlo jazyku a procesu semiózy.

Zvolená perspektíva má potenciál vysvetlit', prečo sú Dobrakovovej naratívy takpovediac obrátené chrbtom $\mathrm{k}$ sféram autora a autorské „,Ja“ sa nestáva predmetom rozprávania. Dobrakovová produkuje zámenné figúry, ktorých autonómnost však uplatnením intratextuality a intertextuality okamžite eliminuje. Toto spochybnenie interpretujem ako stratégiu, ktorá vedie $\mathrm{k}$ zviditel'neniu prítomnosti implikovaného autora. V uvažovanom kontexte produkcie autobiografického účinku je implikovaný autor funkčný práve tým, že je začlenený/rozptýlený/ zainteresovaný na dianí textu bez toho, aby bol vystavený aktívnej zóne jazyka/ semiózy. Ako o tom uvažuje Seymour Chatman, implikovaný autor - ako štruktúrny princíp imanentný naratívu - „vymyslel vypravěče spolu se vším ostatním v narativu [...] namíchal karty právě tímto konkrétním způsobem, způsobil, že právě tyto věci se staly právě těmto postavám, právě těmito slovy nebo $v$ těchto obrazech“, pričom - a to je mimoriadne dôležité - „na rozdíl od vypravěče nám [...] nemůže vůbec nic říct. Nemá žádný hlas, žádný přimý prostředek komunikace. Instruuje nás mlčky, rozvrhem celku“ (Chatman 2008: 154). Implikovaný 
autor nielenže nemôže nič hovorit' (a teda na seba poukazovat'), ale naratív ho ani v žiadnom úseku textu nezachytáva, netematizuje. Implikovaný autor teda nehovorí a nie je o ňom vypovedané, jeho prítomnost' nie je jazykovo/semioticky vyjadrená. Dôsledok je vítaný: vyhnút' sa jazyku/semióze tu znamená vyhnút' sa transformácii na znakovú či fikčnú figúru, čo výhl'adovo otvára nárok na nejazykové ustrojenie subjektivity. ${ }^{19} \mathrm{~V}$ krajnom prípade, domyslené ad infinitum, stojac mimo jazyk, môže iniciovat' účinok, v rámci ktorého môže prestat' byt' vnímaný ako „fikcia a literatúra“.V tejto pozícii-hoci je rekonštruovatel'ný jedine z naratívu (Chatman 2008: 154) - môže vyzývat' k prehliadnutiu svojho literárneho charakteru (pričom práve $\mathrm{k}$ tomuto bodu smeruje kritika mnohých naratológov). To je vo vztahu k auto/biografickým zámerom autora, ktorý naráža na konštitutívne sily semiotiky textu, mimoriadne cenná situácia. Implikovaný autor je totiž „figúra“, ktorá v recepčnom akte môže vystupovat' ako predpoklad udalostí textu aj ich homogenity. Z recepčného hl'adiska sa tak priamo v režime textu inštaluje/ predstiera semiotický model referenta-subjektu, ktorý nemá jazykovú povahu, pretože znaku predchádza (čo je semiotická situácia klasickej autobiografie pred lingvistickým obratom; Finck 1999: 279-289). Tým vytvára podmienky pre recepčnú zámenu s empirickým autorom obývajúcim aktuálny svet. ${ }^{20}$

\section{Záver}

V kontakte s tvorbou I. Dobrakovovej je čitatel' prinútený váhat' medzi referenčným a fikčným čítaním. ${ }^{21}$ Nazdávam sa, že toto váhanie je účinok organizovaný poetikou textu; uplatnením intratextuálnych a intertextuálnych postupov, ktoré spolupracujú na diskreditácii jednotlivých kompozičných dominánt a významotvorných zložiek, dochádza k zdôrazneniu prítomnosti figúry implikovaného autora - „akejsi antropomorfnej entity“ (S. Rimmonová-Kenanová), rekonštruovatelnej jedine z naratívu (S. Chatman), no zaujímajúcej pozíciu nejazykovo ustrojenej subjektivity, ktorá nie je totožná s figúrou autora, no je natol'ko uvol'nená, že k tomuto stotožneniu vyzýva/zvádza (U. Eco). Zdôrazňovat' prítomnost' implikovaného autora, ktorého z jednej strany určujú iba textové udalosti, no ktorý z druhej strany (už takto určený) umožňuje zámenu s empirickým autorom, ${ }^{22}$

19 Pre Shlomith Rimmonovú-Kenanovú je implikovaný autor v Boothovej koncepcii „něčím více než pouhou textovou pozicí, zdá se, že jde o jakousi antropomorfní entitu“ (Rimmonová-Kenanová 2001: 93). Tento bod Boothovej koncepcie bol silno problematizovaný, sama Rimmonová-Kenanová neskôr navrhovala, aby bol implikovaný autor „depersonifikován a vnímán spíše jako soubor implicitních norem než jako mluvčí či hlas (tj. subjekt)“ (Rimmonová-Kenanová 2001: 94). Richard Walsh koncept implikovaného autora zavrhol úplne: „Odpověd', kterou nabízím na svou původní otázku ,Kdo je vypravěč?‘, je následující: Vypravěčje bud'postava, která vypráví, nebo autor. Nic mezi tím neexistuje“ (Walsh 2007: 53). 20 Nemalú úlohu v tom zohráva skutočnost', že implikovaný autor môže byt' s empirickým autorom identický. To, že môže, vyplýva z poznámky S. Rimmonovej-Kenanovej: ,tito dva (autor skutečný a implikovaný) nemusí být, a opravdu často nejsou, identičti““ (Rimmonová-Kenanová 2001: 93).

21 Postupy uplatnené v dielach, ,které můžou u čtenáře vyvolat nejistotu, jaký druh textu čte“ (Soukupová 2012: 21), dôsledne reflektovala Klára Soukupová v diplomovej práci (Re)Konstrukce subjektivity a času vžánru autobiografie. V nadväznosti na výskum Phillipa Lejeuna tu autorka (okrem iného) upozorňuje na problémové situácie vyplývajúce z uzatvorenia románového alebo autobiografického paktu.

22 Vychádzam z Boothovej koncepcie (Booth 2007: 42-51), Walshovej reakcie (Walsh 2007: 55-56) a referencií K. Soukupovej (Soukupová 2012: 30). Soukupová spolu s Walshom poznamenáva, že implikovaný autor $v$ Boothovej koncepcii zaujíma pozíciu medzi reálnym historickým autorom a rozprávačom. Soukupová potom túto situáciu d'alej interpretuje v priesečníku s Lejeunovou koncepciou autobiografického paktu-Boothovho implikovaného autora „se nabízí chápat jako Lejeunova autora“(Soukupová 2012: 30). 
526 dáva I. Dobrakovovej možnost' vytvárat' fikčné svety, dovolujúce čitatel'ovi váhat', či v nich nakoniec predsa len nenachádza životné príbehy autorky. ${ }^{23}$

Ak Dobrakovovej poetika niečo posilňuje, nie je to referencia k oblasti reálneho autora, ale iba práve toto váhanie ako účinok špecifickej konfigurácie textovo-sémantických zložiek. Dobrakovová vo svojich textoch neformuluje - napríklad ako Dominik Tatarka v Navrávačkách -inštrukcie typu „toto je pravda - toto nie je pravda“, ${ }^{24}$ nič v tomto zmysle nerozhoduje. Vyvolat'/organizovat' toto váhanie tejto poetike stačí: váhanie tu totiž nie je stav oslabenej noetickej istoty, ale esteticky produktívnej neistoty, v ňom sa „všetko“ javí ako potenciálne fiktívne a zároveň potenciálne referenčné, a to bez možnosti definitívne sa priklonit' kjednému či druhému. Prekonávat tento modus by bolo deštruktívne. Definitívne sa rozhodnút' pre jeden „pól“ by znamenalo odmietnut' ten druhý, ktorý sa však spolupodiel'a na jeho špecifickosti.

Štúdia je súčastou riešenia grantovej úlohy APVV-18-0043 Slovník diel slovenskej literatúry po roku 1989. Zodpovedný riešitel': doc. Mgr. et Mgr. Ján Gavura, PhD. Doba riešenia: 2018-2022.

\section{Pramene}

BLANCHOT, Maurice, 2004. Literatura a právo na smrt. Přeložil Josef Fulka. Česká literatura, roč. 52, č. 2, s. 194-230. ISSN 0009-0468.

BLANCHOT, Maurice, 2014. Temný Tomášs. Přeložil Petr Janus. Praha: Rubato. ISBN 978-80-87705-28-5.

DOBRAKOVOVÁ, Ivana, 2009. Prvá smrt'v rodine. Bratislava: Albert Marenčin Vydavatel'stvo PT. ISBN 978-80-8114-007-5.

TATARKA, Dominik, 2013. Navrávačky. Bratislava: Artforum. ISBN 978-80-8150-024-4.

\section{Literatúra}

BARBORÍK, Vladimír, 2011. „Literatúra“ verzus výpoved': debut a prvý román Ivany Dobrakovovej. Vlna, roč. 13, č. 46, s. 113-118. ISSN 1335-5341.

BOOTH, Wayne, 2007. Typy vyprávění. Přeložila Martina Knapkova. Aluze, roč. 11, č. 2, s. 42-51. ISSN 1803-3784.

COHNOVÁ, Dorrit, 2009. Co dělá fikci fikcí. Přeložili Milan Orálek a Veronika Klusáková. Praha: Academia. ISBN 978-80-200-1718-5.

ČERNÝ, Václav, 1969. Okénko do světa Franze Kafky. In ČERNÝ, Václav. Studie a eseje z moderni světové literatury. Praha: Československý spisovatel, s. 118-157. ISBN 22-106-69.

DOLEŽEL, Lubomír, 2003. Heterocosmica. Fikce a možnésvěty. Praha: Karolinum. ISBN 80-246-0735-2.

ECO, Umberto, 2010. Lector in fabula. Role čtenáře aneb Interpretační kooperace $\mathrm{v}$ narativních textech. Přeložil Zdeněk Frýbort. Praha: Academia. ISBN 978-80-200-1828-1.

FINCK, Almut, 1999. Pojem subjektu a autorství: K teorii a dějinám autobiografie. In PECHLIVANOS, Miltos - RIEGER, Stefan -STRUCK, Wolfgang-WEITZ, Michael, ed. Úvod do literární vědy. Přeložil Miroslav Petříček. Praha: Herrmann \& synové, s. 279-289. ISBN 80-238-5329-5.

23 Ak čitatel' - vedený poetikou textu - nakoniec pristúpi na myšlienku, že tu „vypráví sám autor, pak se bez implikovaného autora zjevně obejdeme“ (Walsh 2007: 55). To možno vyhodnotit ako potvrdenie úspešnosti princípu rozpadu; orientáciou na autora prestáva implikovaný autor platit', stáva sa zbytočným, je to teda odsunutie implikovaného autora, ktoré vykoná čitatel' vedený/vyzývaný poetikou textu. 24 „To je všetko pravda, tak ako ti to hovorím“ (Tatarka 2013: 88). 
FULKA, Josef, 2004. Předmluva. Česká literatura, roč. 52, č. 2, s. 194-195. ISSN 0009-0468. GENETTE, Gérard, 2007. Fikce a vyprávění. Přeložila Eva Brechtová. Brno-Praha: Ústav pro českou literaturu AV ČR. ISBN 978-80-85778-00-7.

CHATMAN, Seymour, 2008. Př́běh a diskurs. Narativní struktura v literatuře a filmu. Přeložil Milan Orálek. Brno: Host. ISBN 978-80-7294-260-2.

JAMBOR, Ján, 2016. Intertextualita. In MIKULÁŠ, Roman a kolektív. Podoby literárnej vedy. Teórie - Metódy-Smery. Bratislava: Veda, s. 220-236. ISBN 978-80-224-1524-8.

JAREŠ, Michal, 2013. O matkách a dětech. Romboid, roč. 48, č. 9, s. 13-18. ISSN 0231-6714.

KENDRA, Milan, 2020. K dvom tendenciám autobiografickej umeleckej fikcie v slovenskej próze a ich apelovej štruktúre. In SOUČKOVÁ, Marta, ed. K poetologickým a axiologickým aspektom slovenskej literatúry po roku 2000 VI. Prešov: Filozofická fakulta Prešovskej univerzity, s. 19-32. ISBN 978-80-555-2561-7.

KLAPÁKOVÁ, Mária, 2015. Ivana Dobrakovová: Toxo. In GAVURA, Ján - KITTA, Richard -SOUČKOVÁ, Marta, ed. TOP 52013 (slovenská literárna a výtvarná scéna 2013 vodbornej reflexii). Prešov - Košice: Občianske združenie FACE, s. 48-55. ISBN 978-80-89763-14-8.

MIKO, František - POPOVIČ, Anton, 1978. Tvorba a recepcia. Estetická komunikácia a metakomunikácia. Bratislava: Tatran. ISBN 61-922-78.

MÜLLER, Richard, 2012. Implikovaný autor. In MÜLLER, Richard - ŠIDÁK, Pavel, ed. Slovník novějiś literární teorie. Glosár pojmů. Praha: Academia, s. 208-210. ISBN 978-80-200-2048-2.

PAPOUŠEK, Vladimír, 2017. Maxwellův démon. In PAPOUŠEK, Vladimír. Maxwellův démon. Objekty, slovníky a řečové akty v literatuře. Praha: Akropolis, s. 52-63. ISBN 978-80-7470-163-4.

PRUŠKOVÁ, Zora, 2010. „Bellevue beletria“ - biograficky, diskurzívne, pútavo. Romboid, roč. 45 , č. 9, s. 19-24. ISSN 0231-6714.

RIMMONOVÁ-KENANOVÁ, Shlomith, 2001. Poetika vyprávění. Přeložila Vanda Pickettová. Brno: Host. ISBN 80-7294-004-X.

SEKÁČOVÁ, Lucia, 2013. Ozveny Franza Kafku v debute Ivany Dobrakovovej Prvá smrt' $\mathrm{v}$ rodine. In SOUČKOVÁ, Marta, ed. K poetologickým a axiologickým aspektom slovenskej literatúry po roku 2000. Prešov: Filozofická fakulta Prešovskej univerzity, s. 72-80. ISBN 978-80-555-0858-0.

SKALICKÝ, David, 2012. Literatura a zrcadlo přírody: Některé souvislosti Rortyho antireprezentacionalismu a myšlení o literatuře. In VEBEROVÁ, Veronika - BÍLEK, Petr A. - PAPOUŠEK, Vladimír - SKALICKÝ, David, ed. Jazyky reprezentace. Praha: Akropolis, s. 62-73. ISBN 978-80-87481-67-7.

SCHAHADAT, Shamma, 1999. Intertextovost: čtení - text - intertext. In PECHLIVANOS, Miltos-RIEGER, Stefan-STRUCK, Wolfgang-WEITZ, Michael, ed. Úvod do literární védy. Přeložil Miroslav Petříček. Praha: Herrmann \& synové, s. 357-367. ISBN 80-238-5329-5.

ŠMÍDOVÁ-MATOUŠOVÁ, Olga, 2014. Auto/biografie, sociologie a kolektivní pamět. In MASLOWSKI, Nicolas - ŠUBRT, Jiří, ed. Kolektivní pamět'. K teoretickým otázkám. Praha: Karolinum, s. 236-256. ISBN 978-80-246-2689-5.

SOUČKOVÁ, Marta, 2012. Ivana Dobrakovová BELLEVUE. In GAVURA, Ján-KITTA, Richard -SOUČKOVÁ, Marta, ed. TOP 52010 (slovenská literárna a výtvarná scéna 2010 vodbornej reflexii). Prešov: Občianske združenie FACE, s. 52-58. ISBN 978-80-971271-0-7.

SUCHÁNKOVÁ, Miriam, 2010. V obkolesení smrti. RAK, roč. 15, č. 1, s. 33-35. ISSN 1335$-1702$.

WALSH, Richard, 2007. Kdo je vypravěč? Přeložil Milan Orálek. Aluze, roč. 12, č. 1, s. 48-60. ISSN 1803-3784.

ZAJAC, Peter, 2013. Prítomnost́ súčasnej slovenskej literatúry (Prolegomena). In SOUČKOVÁ, Marta, ed. Kpoetologickým a axiologickým aspektom slovenskej literatúry po roku 2000. Prešov: Filozofická fakulta Prešovskej univerzity v Prešove, s. 8-20. ISBN 978-80-555-0858-0.

\section{Elektronické zdroje}

BYSTRZAK, Magdalena, 2018. Monológy do prázdna. PLAV [online]. Bratislava: Platforma pre literatúru a výskum (o. z. PLAV). ISSN 2453-9147. Dostupné online: https://plav.sk/ node $/ 135$

BŽOCH, Jozef, 2009. Rafinovanosti úspešnej debutantky. SME [online], 10. 7. 2009. Dostupné online: <https://kultura.sme.sk/c/4927221/rafinovanosti-uspesnej-debutantky.html>

FERENČUHOVÁ, Mária:Vypísat'sa z psychózy, hoci by aj bola vymyslená. 6. 7.2009. Dostupné online: www.inland.sk (https://www.martinus.sk/?uItem=100265) 
528 KLAPÁKOVÁ, Mária, 2012. Priestor liečebného centra (I. Dobrakovová: Bellevue). In CHOVANEC, Marek, ed. 7. študentská vedecká konferencia. Prešov: Prešovská univerzita v Prešove, s. 927-934. ISBN 978-80-555-0516-9. Dostupné online: <https://www.

oj pulib.sk/web/pdf/web/viewer.html?file=/web/kniznica/elpub/dokument/Chovanec3/

जิ subor/9788055505169.pdf>

오 SOUKUPOVÁ, Klára, 2012. (Re)Konstrukce subjektivity a časuvžánru autobiografie. Diplomová

$\infty$ práce [online]. Praha: Univerzita Karlova v Praze. Dostupné online: $<$ https://www.academia.

일 edu/1240248/_Re_Konstrukce_subjektivity_a_\%C4\%8Dasu_v_autobiografii_Re_Construction_of_the_Subjectivity_and_Time_in_the_Autobiography>

TARANENKOVÁ, Ivana, 2010. Vo vlastných pascách. Pravda [online], 14. 11. 2010. Dostupné online: $<$ https://kultura.pravda.sk/kniha/clanok/39561-kniha-tyzdna-vo-vlastnych-pascach/>

PhDr. Marcel Forgáč, PhD.

Katedra slovenskej literatúry

a literárnej vedy

Inštitút slovakistiky a mediálnych

štúdií

Filozofická fakulta Prešovskej

univerzity v Prešove

Ul. 17. novembra č. 1

08001 Prešov

Slovenská republika

E-mail: marcel.forgac@unipo.sk 